\title{
Functional comparison of the HTLV-1 and HTLV-2 antisense viral proteins: implications for pathogenesis
}

\author{
Amanda R Panfil ${ }^{1,2}$, Nathan Dissinger ${ }^{1,2}$, Kristina Landes ${ }^{1,2}$, Patrick L Green ${ }^{1,2,3,4^{*}}$ \\ From 17th International Conference on Human Retroviruses: HTLV and Related Viruses \\ Trois llets, Martinique. 18-21 June 2015
}

HTLV-1 and HTLV-2 are highly related retroviruses that transform T-lymphocytes in cell culture, but display distinct pathobiology in vivo. HTLV-1 is the causative infectious agent of adult T-cell leukemia/lymphoma (ATL) and a neurodegenerative disease (HAM/TSP), whereas HTLV-2 is nonpathogenic. HTLV-1 encodes a protein on the antisense strand of its proviral genome called HTLV-1 basic leucine zipper (bZIP) factor (HBZ), which inhibits Tax-mediated viral transcription and is required for high proviral load and efficient viral persistence. Studies have shown that HBZ also modulates several cellular pathways that include activating protein-1 (AP-1), NF- $\kappa$ B , and innate immune responses. HTLV-2 also encodes a protein on the antisense genome strand named antisense protein of HTLV-2 (APH-2). Like HBZ, APH-2 also inhibits Tax-mediated viral transcription. However, we show that unlike HBZ, loss of APH-2 results in enhanced viral replication and viral persistence in infected rabbits. This led us to hypothesize that HBZ and APH-2 modulate cellular pathways differently, which translates to the distinct HTLV-1 and HTLV-2 pathobiology. In this study we directly compared APH-2 and HBZ biologic properties and functions on known HBZ-modulated pathways. We provide evidence that APH-2 protein is significantly less stable than HBZ protein (half-life approximately $30 \mathrm{~m}$ vs. $6.5 \mathrm{~h}$ ). Despite the difference in protein half-life, HTLV-2 does not compensate for this instability by increasing APH-2 mRNA copy number. Additionally, APH-2 and HBZ share similar mRNA stability measurements. We further show that APH-2 inhibits the transforming growth factor $\beta$ (TGF- $\beta$ )

\footnotetext{
* Correspondence: green.466@osu.edu

${ }^{1}$ Center for Retrovirus Research, The Ohio State University, Columbus, $\mathrm{OH}$ 43210, USA

Full list of author information is available at the end of the article
}

signaling pathway in contrast to HBZ's enhancement. Like HBZ, APH-2 is able to inhibit the cellular transcription factors p65 (NF- $\kappa \mathrm{B})$ and interferon response factor (IRF)-1. Taken together our results indicate that APH-2 is limited in some functions it shares with HBZ. Further studies should focus on distinct HBZ functions and interacting pathways to find new potential therapeutic targets for HTLV-1 disease.

\section{Authors' details}

${ }^{1}$ Center for Retrovirus Research, The Ohio State University, Columbus, $\mathrm{OH}$ 43210, USA. ${ }^{2}$ Department of Veterinary Biosciences, The Ohio State University, Columbus, OH 43210, USA. ${ }^{3}$ Department of Molecular Virology, Immunology and Medical Genetics, The Ohio State University, Columbus, $\mathrm{OH}$ 43210, USA. ${ }^{4}$ Comprehensive Cancer Center and Solove Research Institute, The Ohio State University, Columbus, OH 43210, USA.

Published: 28 August 2015

doi:10.1186/1742-4690-12-S1-08

Cite this article as: Panfil et al.: Functional comparison of the HTLV-1 and HTLV-2 antisense viral proteins: implications for pathogenesis. Retrovirology 2015 12(Suppl 1):08.

Submit your next manuscript to BioMed Central and take full advantage of:

- Convenient online submission

- Thorough peer review

- No space constraints or color figure charges

- Immediate publication on acceptance

- Inclusion in PubMed, CAS, Scopus and Google Scholar

- Research which is freely available for redistribution

Submit your manuscript at www.biomedcentral.com/submit
() Biomed Central 